\section{The Indications for Probiotics in Australia and Their Regulation}

\section{Anjali Kumar ${ }^{1 *}$, Carlin Chen ${ }^{2}$, Samantha Elliott ${ }^{3}$, Emmanuella Mensah $^{2}$ and Ken J Harvey ${ }^{4 *}$}

${ }^{1}$ Department of Medicine, Institute of Life Science, Swansea University, Swansea, United Kingdom

${ }^{2}$ Monash University Faculty of Medicine, Nursing and Health Sciences, Clayton, Australia

${ }^{3}$ Monash University Faculty of Science, Clayton, Australia

${ }^{4}$ Institute of Evidence-Based Healthcare, Bond University Faculty of Health Sciences and Medicine, University Drive, Robina, Australia

\begin{abstract}
Currently, 510 self-certified products containing probiotics are listed on the Australian Register of Therapeutic Goods (ARTG). We found $48 \%$ contained only probiotic ingredients; the remainder had multiple additional ingredients. The indications used (and claims made) were mainly non-specific, appeared to lack evidence, and encouraged unnecessary use.
\end{abstract}

\section{Body}

Probiotics are defined as "live microorganisms that, when administered in adequate amounts, confer a health benefit on the host" [1]. The Therapeutic Goods Administration (TGA) regulates products containing probiotics as complementary medicines. Currently, all are listed products (labelled AUST L) for which sponsors self-certify regulatory compliance, including that they hold evidence for the indications selected [2].

We extracted public summary documents from the Australian Register of Therapeutic Goods (ARTG) by searching for common probiotic genera, 'Lactobacillus* or Bifidobacterium* or Streptococcus* or Saccharomyces* or Bacillus*' on 23 June 2021. A Python-based data extraction program automated the download of ARTG summaries and

${ }^{*}$ Corresponding authors: Anjali Kumar, Department of Medicine, Swansea University, Institute of Life Science Swansea, United Kingdom, Tel: +44 7402361336; E-mail: 2001073@swansea.ac.uk

Ken J Harvey, Institute of Evidence-Based Healthcare, Bond University Faculty of Health Sciences and Medicine, University Drive, Robina, Australia, Tel: +61 419181910; E-mail: ken.harvey@medreach.com.au

Citation: Kumar A, Chen C, Elliott S, Mensah E, Harvey KJ (2021) The Indications for Probiotics in Australia and Their Regulation. J Altern Complement Integr Med 7: 206.

Received: November 10, 2021; Accepted: November 12, 2021; Published: November 19, 2021

Copyright: (c) 2021 Kumar A, et al. This is an open-access article distributed under the terms of the Creative Commons Attribution License, which permits unrestricted use, distribution, and reproduction in any medium, provided the original author and source are credited. the extraction of permitted indications and ingredients. This software enabled the analysis of 510 products; $48 \%$ contained only probiotic ingredients, the remainder had multiple additional ingredients.

None of the probiotic ingredients listed in public summaries contained information about strains. This is a significant omission, given that the benefits of probiotics are strain-specific [3]. It also resulted in ARTG summaries listing the same probiotic microorganism in different dosages. For example, the public summary document of ARTG entry 339468, 'Probiotics for 60+ Year', lists Lactobacillus plantarum as an active ingredient four times, with three showing the same doses and one a different amount.

The most common permitted indications used for probiotic products were non-specific gastrointestinal and immune support that appeared to have little supporting evidence. For example, 'Maintain/ support healthy digestion' and 'helps stimulate a healthy immune system response'. Although there is some evidence to suggest that specific probiotic strains are beneficial in preventing and treating specific conditions such as antibiotic-associated diarrhoea or irritable bowel syndrome, these were not among the ten most common permitted indications we found. Some permitted indications appeared to have no evidence to support them. For example, ARTG entry 353540, 'Inner health neuro balance' (ingredients: Lactobacillus plantarum and Lactobacillus rhamnosus) has 17 permitted indications including, 'Calms the mind', 'Maintain/support memory/mental recall' and 'Support healthy emotional $/$ mood balance'.

Around $52 \%$ of all probiotic products reviewed contained non-probiotic ingredients. These combinations also appeared to have little evidence to support them apart from possibly broadening their market appeal. For example, some products contained vitamins and enzymes such as pyridoxine hydrochloride and amylase, none of which has been investigated to promote or assist the efficacy and growth of probiotics. It would be helpful if the TGA required permitted indications to be linked to ingredients.

Others have expressed concern that commercial interests, coupled with lack of sufficient medical regulation, make objective interpretation of the benefits of most probiotic products close to impossible [4]. We agree. The TGA should conduct post-marketing surveillance on probiotic products to ensure that the permitted indications (and claims made) are evidence-based.

\section{References}

1. Food and Agriculture Organization (2006) Probiotics in Food: Health and Nutritional Properties and Guidelines for Evaluation Rome. Food and Agriculture Organization, World Health Organisation, Rome, Italy.

2. Therapeutic Goods Administration (2021) How we regulate medicines. Therapeutic Goods Administration, Australia.

3. Rijkers GT, Bengmark S, Enck P, Haller D, Herz U, et al. (2010) Guidance for Substantiating the Evidence for Beneficial Effects of Probiotics: Current Status and Recommendations for Future Research. J Nutr 140: 671-676.

4. Suez J, Zmora N, Segal E, Elinav E (2019) The pros, cons, and many unknowns of probiotics. Nat Med 25: 716-729. 


\section{H}

Advances In Industrial Biotechnology | ISSN: 2639-5665

Advances In Microbiology Research | ISSN: 2689-694X

Archives Of Surgery And Surgical Education | ISSN: 2689-3126

Archives Of Urology

Archives Of Zoological Studies | ISSN: 2640-7779

Current Trends Medical And Biological Engineering

International Journal Of Case Reports And Therapeutic Studies | ISSN: 2689-310X

Journal Of Addiction \& Addictive Disorders | ISSN: 2578-7276

Journal Of Agronomy \& Agricultural Science | ISSN: 2689-8292

Journal Of AIDS Clinical Research \& STDs | ISSN: 2572-7370

Journal Of Alcoholism Drug Abuse \& Substance Dependence | ISSN: 2572-9594

Journal Of Allergy Disorders \& Therapy | ISSN: 2470-749X

Journal Of Alternative Complementary \& Integrative Medicine | ISSN: 2470-7562

Journal Of Alzheimers \& Neurodegenerative Diseases | ISSN: 2572-9608

Journal Of Anesthesia \& Clinical Care | ISSN: 2378-8879

Journal Of Angiology \& Vascular Surgery | ISSN: 2572-7397

Journal Of Animal Research \& Veterinary Science | ISSN: 2639-375

Journal Of Aquaculture \& Fisheries | ISSN: 2576-5523

Journal Of Atmospheric \& Earth Sciences | ISSN: 2689-8780

Journal Of Biotech Research \& Biochemistry

Journal Of Brain \& Neuroscience Research

Journal Of Cancer Biology \& Treatment | ISSN: 2470-7546

Journal Of Cardiology Study \& Research | ISSN: 2640-768X

Journal Of Cell Biology \& Cell Metabolism | ISSN: 2381-1943

Journal Of Clinical Dermatology \& Therapy | ISSN: 2378-8771

Journal Of Clinical Immunology \& Immunotherapy | ISSN: 2378-8844

Journal Of Clinical Studies \& Medical Case Reports | ISSN: 2378-880

Journal Of Community Medicine \& Public Health Care | ISSN: 2381-1978

Journal Of Cytology \& Tissue Biology | ISSN: 2378-9107

Journal Of Dairy Research \& Technology | ISSN: 2688-9315

Journal Of Dentistry Oral Health \& Cosmesis | ISSN: 2473-6783

Journal Of Diabetes \& Metabolic Disorders | ISSN: 2381-201X

Journal Of Emergency Medicine Trauma \& Surgical Care | ISSN: 2378-8798

Journal Of Environmental Science Current Research | ISSN: 2643-5020

Journal Of Food Science \& Nutrition | ISSN: 2470-1076

Journal Of Forensic Legal \& Investigative Sciences | ISSN: 2473-733X

Journal Of Gastroenterology \& Hepatology Research | ISSN: 2574-2566
Journal Of Genetics \& Genomic Sciences | ISSN: 2574-2485

Journal Of Gerontology \& Geriatric Medicine | ISSN: 2381-8662

Journal Of Hematology Blood Transfusion \& Disorders | ISSN: 2572-2999

Journal Of Hospice \& Palliative Medical Care

Journal Of Human Endocrinology | ISSN: 2572-9640

Journal Of Infectious \& Non Infectious Diseases | ISSN: 2381-8654

Journal Of Internal Medicine \& Primary Healthcare | ISSN: 2574-2493

Journal Of Light \& Laser Current Trends

Journal Of Medicine Study \& Research | ISSN: 2639-5657

Journal Of Modern Chemical Sciences

Journal Of Nanotechnology Nanomedicine \& Nanobiotechnology | ISSN: 2381-2044

Journal Of Neonatology \& Clinical Pediatrics | ISSN: 2378-878X

Journal Of Nephrology \& Renal Therapy | ISSN: 2473-7313

Journal Of Non Invasive Vascular Investigation | ISSN: 2572-7400

Journal Of Nuclear Medicine Radiology \& Radiation Therapy | ISSN: 2572-7419

Journal Of Obesity \& Weight Loss | ISSN: 2473-7372

Journal Of Ophthalmology \& Clinical Research | ISSN: 2378-8887

Journal Of Orthopedic Research \& Physiotherapy | ISSN: 2381-2052

Journal Of Otolaryngology Head \& Neck Surgery | ISSN: 2573-010X

Journal Of Pathology Clinical \& Medical Research

Journal Of Pharmacology Pharmaceutics \& Pharmacovigilance | ISSN: 2639-5649

Journal Of Physical Medicine Rehabilitation \& Disabilities | ISSN: 2381-8670

Journal Of Plant Science Current Research | ISSN: 2639-3743

Journal Of Practical \& Professional Nursing | ISSN: 2639-568

Journal Of Protein Research \& Bioinformatics

Journal Of Psychiatry Depression \& Anxiety | ISSN: 2573-0150

Journal Of Pulmonary Medicine \& Respiratory Research | ISSN: 2573-0177

Journal Of Reproductive Medicine Gynaecology \& Obstetrics | ISSN: 2574-2574

Journal Of Stem Cells Research Development \& Therapy | ISSN: 2381-2060

Journal Of Surgery Current Trends \& Innovations | ISSN: 2578-7284

Journal Of Toxicology Current Research | ISSN: 2639-3735

Journal Of Translational Science And Research

Journal Of Vaccines Research \& Vaccination | ISSN: 2573-0193

Journal Of Virology \& Antivirals

Sports Medicine And Injury Care Journal | ISSN: 2689-8829

Trends In Anatomy \& Physiology | ISSN: 2640-7752

Submit Your Manuscript: https://www.heraldopenaccess.us/submit-manuscript 